\title{
Library services to
}

\section{extension students}

\author{
By Sherre H. Dryden \\ Librarian, University of South Carolina \\ Salkehatchie Campus Library
}

\section{USC's Walterboro branch library grows to meet the needs of Salkehatchie students.}

W hen the Salkehatchie Campus of the University of South Carolina began offering classes in Walterboro, 45 miles from its base in Allendale, library services for those students were not planned. It soon became clear, however, that as the program in Walterboro grew, some type of library support for the curriculum was essential.

Service was haphazard for several years until, in September 1982, student and faculty demand for library materials became so great that a proposal, based on the ACRL "Guidelines for Extended Campus Library Services” (CむRL News, March 1982), was drafted and presented to the campus administration for approval. The proposal, which was accepted, recommended a two-phase program of library development, beginning with public library support of the curriculum and culminating in the establishment of a branch library by the following fall semester. The recommended timeframe was followed, and the Walterboro branch of the USC Salkehatchie Library began operation in Fall 1983.

No special funding has ever been allocated by the University to assist with development of the Walterboro branch. In fact, the library experienced a significant budget reduction in the branch's second year of operation. That year, 1984-85, the librarian's budget proposal to the Academic Affairs Committee, which serves as the li- brary advisory committee, called for the entire materials budget to be allocated on a per FTE (full-time equivalent student) basis equally between Allendale and Walterboro. The committee recommended against this, so a lump sum was allocated for Walterboro acquisitions. The same recommendation met with the same response in the branch's third year, 1985-86. Despite this lack of funding, and perhaps because of it, the Walterboro branch has flourished.

Because of the budget constraints, emphasis for the first years has been on building a collection through relocating duplicate Allendale materials and acquiring gift materials, locating and training staff and developing a program of services that not only meets the needs of the students, but that also actively solicits their use of the library.

The collection has grown rapidly. Over 1,400 volumes, largely gifts, were added between the branch's opening and December 1985. A few new materials, primarily reference sources, have been purchased specifically for Walterboro. Although there are times when duplicate holdings are necessary, they are avoided if possible. A preferable solution is for Allendale to have one source on a topic and Walterboro to have another.

Both libraries subscribe to Magazine Index, but issues of more specialized indexes are sent from Allendale when they are superseded. So that Walter- 
boro students will have the opportunity to learn some research techniques, Allendale librarians compile bibliographies from periodical index volumes not available in Walterboro. The Walterboro branch subscribes to ten periodicals (eight of which are unique titles) but all back files are maintained in Allendale. Expensive or specialized reference sources are housed in Allendale unless requested to support research by a particular class or faculty member.

Special arrangements are frequently required to provide Walterboro students with the materials they need, but these arrangements have no rigid structure. The librarians work closely with one another and other faculty members to determine needs and to assure that all options are considered. Whatever seems the best solution for each case is carried out.

Intra- and interlibrary loan are used heavily to obtain materials for Walterboro faculty and students. The USC University and Four Year Campus Libraries use an internal electronic mail system to process loan requests. An ILL librarian, a paraprofessional and a number of students handle requests at the Library Processing Center (LPC) on the University's central campus in Columbia. Requests that cannot be filled within the USC system are routed through the OCLC Interlibrary Loan Subsystem.

Interlibrary loan requests from Walterboro patrons are sent first to Allendale, then on to other USC libraries if Allendale cannot fill the request (a union list of serials is available at each library and the LPC maintains a union title file). There are few restrictions on who may request loans and from which libraries loans are requested. Although the majority of requests come from students and faculty, community patrons may also borrow through ILL. The Walterboro branch received over 800 ILLs in 1984-85, well over four items for every student, faculty member, and community patron associated with the branch.

Reference questions may also be forwarded to other libraries if resources are not sufficient in Walterboro. Again, the policy of routing first to Allendale is followed. Questions range from readyreference queries that can be solved by telephone to questions requiring in-depth research. The Allendale librarian completes the research, then forwards the answer and any supporting material to Walterboro. If requests cannot be handled in Alledale, they are usually sent to the LPC where personnel use the resources of the Columbia campus libraries.

In some cases, large segments of the Allendale collection are temporarily relocated to Walterboro. This is most frequently done when a course being taught in Walterboro is not also offered in $\mathrm{Al}$ lendale. Other arrangements include having faculty (who often teach sections of a course in both locations) assign different research topics in Allendale and Walterboro, preparing special bibliogra- phies of material available on assigned topics and providing Walterboro students with free photocopies of Allendale-based materials. Whenever possible, even if artificial means are necessary, normal library conditions are provided to Walterboro students.

Admittedly, the sources available locally to USC Salkehatchie students in Walterboro do not match those in the Allendale library. However, care is taken to see that Walterboro students have whatever they need to meet the same research requirements expected of Allendale students. As the Walterboro branch grows, it is possible that some of the services now provided will become unnecessary, or will not be used to the same extent. It is more probable that most of the services will be expanded and used in both Allendale and Walterboro to increase the library resources available to all USC Salkehatchie students.

\section{Letters}

\section{Library service in India}

To the Editor:

In the interview with Girja Kumar conducted by William Sheh Wong (C\&RL News, December 1985, pp. 633-36), Mr. Kumar did not elaborate on his generalized statement of having found the task of running a large library a "frustrating experience" and that the "academic library system is becoming socially irrelevant." My own experience as an observer of contemporary Indian academic libraries is that the framework for maximizing academic library resources does exist but motivation is lacking at various levels, especially in the top echelons of Indian librarianship.

It is also unfortunate that Mr. Wong recorded the statements of university librarians without checking their accuracy or examining the quality of their monographs. - B.K. Kumar, Documentation Officer, Dep't of Chinese and Japanese Studies, University of Delhi.

\section{The author replies:}

It is fine if Mr. Kumar would like to express his opinion on library services and information policy in India. Because I asked and obtained curriculum vitae from all except one of the librarians I mentioned in my article, I believe that my title-count of their publications is fairly accurate. These records support my impression that there is a keen interest in research and publication activities among Indian academic librarians. I had not intended to pass judgment on the quality of these publications.-William S. Wong, Asian Librarian, University of Illinois, Urbana. 